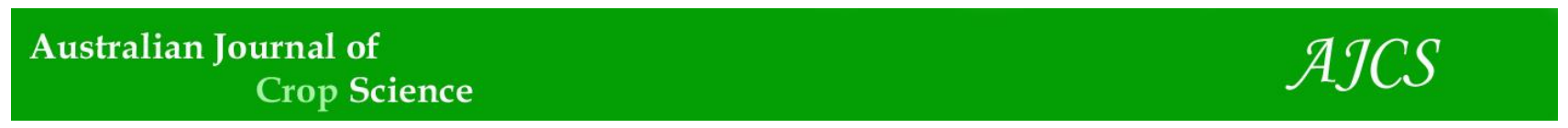

AJCS 15(04):586-593 (2021)

ISSN:1835-2707

doi: 10.21475/ajcs.21.15.04.p3019

\title{
Retranslocation of nutrients in coffee leaves of cultivars Red Catuaí IAC 144 and IAC 125 RN.
}

\section{Carlos Diego da Silva ${ }^{1 *}$, Alian Cássio Pereira Cavalcante ${ }^{2}$, Marcos Fabian Sanabria Franco ${ }^{1}$, Pedro Ruben Viera Fariña ${ }^{4}$, Guilherme Antônio Vieira de Andrade ${ }^{3}$, Leonardo Angelo de Aquino ${ }^{1}$}

\author{
${ }^{1}$ Universidade Federal de Viçosa (UFV), Rio Paranaíba, MG, Brasil \\ ${ }^{2}$ Universidade Federal de Viçosa (UFV), Viçosa, MG, Brasil \\ ${ }^{3}$ Universidade Federal de Lavras (UFLA), Lavras, MG, Brasil \\ ${ }^{4}$ Instituto Paraguaio de Tecnologia Agrária - IPTA, Chore, San Pedro, Paraguai
}

*Corresponding author: carlosdiego_agro@hotmail.com

\section{Abstract}

Knowledge of the retranslocation of nutrients in plants can help in the management of coffee fertilization, especially with regard to the ideal time and method of application and the need for installments. The aim of this study was to evaluate the retranslocation of nutrients in coffee leaves of two varieties. The treatments consisted of two varieties of coffee (Red Catuaí IAC 144 and IAC 125 RN) and coffee leaves in four phenological stages (young leaves, diagnostic, senescent and deciduous). The index leaf of Catuaí Vermelho IAC 144 showed the highest photosynthetic rate and stomatal conductance, while the internal conductance of $\mathrm{CO}_{2}$ was higher in young and senescent leaves, and the index and senescent leaves showed the highest efficiencies in the use of water. The chlorophyll $a, b$ and total chlorophyll has higher concentrations in the index leaf, while the highest carotenoids occurred in young and senescent leaves. The highest levels of N, P, K and Zn in Catuaí Vermelho IAC 144 was occurred in young leaves and the highest $\mathrm{Ca}$ and $\mathrm{Fe}$ in senescent leaves. The highest levels of N, P and K in the IAC $125 \mathrm{RN}$ variety was occurred in young leaves, Ca and Mg in deciduous leaves and $S$ in senescent and deciduous leaves. Nutrients with low mobility in the plant must be parceled, the application of $\mathrm{Zn}$ leaves is an alternative method of supplying this nutrient, as it has retranslocation via phloem.

Keywords: Coffea arabica. Gas exchange. Pigments. Remobilisations.

\section{Introduction}

The variability and seasonality of nutrient availability in the soil may depend on fertilisation, plant demand, and water availability, which can compromise the vegetative and reproductive development of coffee trees. The reserves and subsequent retranslocation of nutrients contribute to meeting the initial demand for developing organs, even with delayed fertilisation or if the water availability in the soil is not adequate. Thus, the absorption pattern and its mobility are fundamental for understanding the nutrient flows in plants and for the management of fertilisation (Brant and Chen, 2015).

Nutrient re-translocation occurs through the phloem, and mature leaves become sources to support the growth of young organs (Abdallah et al., 2010), such as the roots, branches, stems, and fruits (Lima Filho and Malavolta, 2003). After nutrient retranslocation, the leaves considered to be sources enter the senescence process (Avice and Etienne, 2014).

Senescence occurs before any yellowing of the leaves can be observed. Its main function is the well-organised catabolism of cellular constituents (Clément et al., 2018) to redirect the formation of cellular structures in the young parts of the plant. It is essential that cells stay alive longer for nutrient recycling to occur (Diaz et al., 2008).
The retranslocation of nutrients through the phloem depends on its mobility in the plant. Macronutrients such as $\mathrm{N}, \mathrm{P}, \mathrm{K}, \mathrm{Mg}$, and $\mathrm{S}$ are highly mobile in the phloem; $\mathrm{Ca}$, because it is a nutrient that makes up the cell wall, is not relocated via the phloem; and the micronutrients $\mathrm{Fe}, \mathrm{Zn}, \mathrm{Cu}$, $\mathrm{Ni}, \mathrm{Mo}, \mathrm{B}$, and $\mathrm{Cl}$, but not $\mathrm{Mn}$, have moderate mobility in the phloem (White, 2012).

In addition to the retranslocation of nutrients to meet the demand for new leaves, coffee flowers are a strong drain of nutrients (Malavolta et al., 2002). In addition to the flowers, the developing fruits can generate the excessive mobilisation of nutrients from the mature leaves, causing marked defoliation in the coffee tree. This is due to the low ratio between the leaves and fruits (Rena et al., 1983). In three-year-old plants, nutrients that are relocated to flower buds are responsible for meeting up to $24 \%$ of the demand for this organ. From leaf senescence, the chlorophyll molecule is degraded, releasing nitrogen, whose storage forms are mainly proteins and amino acids (Maillard et al., 2015).

Reichardt et al. (2009) reported that after two years of application of ammonium sulphate, at doses of 280 (first year) and 350 (second year) $\mathrm{kg} \mathrm{ha}^{-1}$ of $\mathrm{N}$ in four equal applications carried out during the positive growth rate period, $\mathrm{N}$ recoveries of fertiliser were $19.1 \%$ for the aerial 
part and $9.7 \%$ for the roots. Phosphorus has an accumulation of $14.2 \mathrm{~g} \mathrm{plant}^{-1}, 33 \%$ of which is accumulated in the orthotropic branch, $12 \%$ in the plagiotropic branches, $24 \%$ in the leaves, $16 \%$ in the fruits, and $15 \%$ in the roots. For potassium, $30 \%$ is accumulated in the leaves, $25 \%$ in the orthotropic branch, $12 \%$ in the plagiotropic branches, $19 \%$ in the fruits, and $14 \%$ in the roots (Bragança et al., 2008). The accumulation of nutrients in most of the root aerial parts represents an alternative source of nutrients in periods of scarcity in the soil and can be remobilised according to the demand of the plant.

General assessments of the retranslocation of most nutrients during growth are well documented for annual crops and scarce for tree crops, such as coffee. The retranslocation pattern can be influenced by species and variety, which would result in different leaf sampling strategies for leaf diagnosis and fertiliser management. The objective of this research was to evaluate the retranslocation of macro and micronutrients, gas, and pigment exchanges in leaves at different phenological stages in the culture of the coffee varieties Red Catuaí IAC 144 and IAC 125 RN.

\section{Results}

\section{Physiological analyses}

The index leaf of the Red Catuai IAC 144 variety has a higher photosynthetic rate than do the other leaves of this variety. The net assimilation rate is similar between young and senescent leaves for the Red Catuai IAC 144 variety. In the IAC $125 \mathrm{RN}$ variety, the net assimilation rate was the same among the three analysed leaves (Figure 2a).

Higher stomatal conductance values were observed in young leaves. Again, the diagnostic sheet of Red Catuaí IAC 144 showed greater stomatal conductance than did the same sheet of IAC 125 RN (Figure 2b).

The internal conductance of $\mathrm{CO}_{2}$ showed higher values in young and senescent leaves. The diagnostic leaves showed the lowest values of internal conductance. This result is similar for both varieties. Moreover, its result is the inverse of the photosynthesis and instantaneous efficiency values of carboxylation (Figure 2c).

The efficiency of water use by the leaves is the reverse of the process of transpiration and stomatal conductance. It was observed that the index and senescent leaves were more efficient in the use of water (Figure $2 \mathrm{~d}$ ).

\section{Chlorophyll analysis}

The chlorophyll $a$, chlorophyll $b$, and total chlorophyll contents did not show any significant difference between cultivars. However, the levels of these pigments are dependent on the leaf analysed within each variety. The variety Red Catuaí IAC 144 showed no statistical difference in the chlorophyll $a$, chlorophyll $b$, and total chlorophyll contents, and total in young leaves and index; however, senescent leaves have low levels of these pigments. The variety IAC $125 \mathrm{RN}$ has the highest chlorophyll $a$, chlorophyll $b$, and total chlorophyll contents in the index leaf (Figures $2 a, b$, and $c)$.

The carotenoid content in the leaves follows an inverse pattern of the other pigments, as it is related to photoprotection; it is expected to present low levels in leaves that are photosynthetically active. In the variety Red Catuai IAC 144, the highest levels of carotenoids were found in the young and senescent leaves, the index leaf had higher levels of chlorophyll $a, b$, and total chlorophyll; therefore, its photoprotection activity is low, which is reflected in the lower levels of carotenoids. The variety IAC 125 RN showed no difference in this pigment between the analysed leaves (Figure 2d).

\section{Nutrient content}

Young leaves showed higher levels of $\mathrm{N}, \mathrm{P}$, and $\mathrm{K}$ than did older leaves. This reduction occurs because the nutrients mentioned are mobile in the plant, being relocated via the phloem according to the plant's nutritional demand.

In the leaves of the Red Catuai IAC 144 variety, the lowest $\mathrm{Mg}$ content occurs in the index leaf and there is no difference in this content in the other leaves. In the IAC 125 $\mathrm{RN}$ variety, the $\mathrm{Mg}$ contents were similar in young, index, and senescent leaves, and these were lower than in deciduous leaves. As $\mathrm{Ca}$ is a structural nutrient, it is not retranslated and accumulates in older leaves. The showed different patterns of content between the two cultivars; in Red Catuaí IAC 144 it did not show significant difference. In IAC 125 RN, it accumulated in senescent and deciduous leaves, as an example of $\mathrm{Ca} O \mathrm{~S}$ is practically not retranslated, as it is part of fixed organic compound cell structures (Table 2).

The highest Fe content was found in the deciduous leaves of both varieties, and $\mathrm{Cu}$ showed the highest content in the deciduous leaf of the IAC $125 \mathrm{RN}$ variety. Mn showed a significant difference only in the variety IAC $125 \mathrm{RN}$; this micronutrient is considered to be less mobile in the plant; therefore, it tends to accumulate in older leaves. $\mathrm{Zn}$ has low retranslocation in the plant. In the Red Catuaí IAC 144 variety, $\mathrm{Zn}$ was retranslated to young leaves, which may be related to the greater availability of this nutrient at the time of development of younger tissues. In the variety IAC 125 $\mathrm{RN}$, there was variation in its accumulation: there was a decrease from the young leaf to the index leaf and then an increase in the senescent and deciduous leaves.

\section{Nutrient re-translocation}

The retranslocation of macronutrients in the varieties Red Catuaí IAC 144 and IAC 125 RN was occurred at higher rates in the index leaf than in the young leaf. The sequence of retranslocation of nutrients was $\mathrm{P}>\mathrm{K}>\mathrm{N}>\mathrm{Mg}>\mathrm{S}$. The retranslocation of the senescent leaf to the index leaf in the Red Catuai IAC 144 variety occurred for macronutrients in the order $\mathrm{P}>\mathrm{N}>\mathrm{K}$. In the variety IAC $125 \mathrm{RN}$, the retranslocation of macronutrients from the senescent leaf to the index leaf occurred in the sequence $\mathrm{P}>\mathrm{N}>\mathrm{K}>\mathrm{Mg}>\mathrm{S}$. The retranslocation of the deciduous leaf to the senescent leaf showed a difference in the order of nutrients between the varieties. In Red Catuai IAC 144, the retranslocation sequence occurred in the $\mathrm{P}>\mathrm{S}>\mathrm{K}>\mathrm{N}>\mathrm{Mg}$ sequence. In the IAC 125 RN variety, retranslocation was in the following order: $\mathrm{P}>\mathrm{K}>\mathrm{Na}>\mathrm{N}>\mathrm{S}>\mathrm{Mg}$ (Table 2).

The retranslocation of micronutrients from the index leaf to the young leaf in the variety Red Catuai IAC 144 occurred as follows: $\mathrm{Zn}>\mathrm{B}>\mathrm{Fe}>\mathrm{Cu}>\mathrm{Mn}$. In the variety IAC $125 \mathrm{RN}$, retranslocation was greater for $\mathrm{Zn}$ and followed the order $\mathrm{Cu}$ $>\mathrm{B}>\mathrm{Fe}>\mathrm{Mn}$ (Table 2). The variety Red Catuaí IAC 144 showed retranslocation of the senescent leaf to the index leaf only with Fe: 44.23\% was retranslated. IAC $125 \mathrm{RN}$ showed the retranslocation of $\mathrm{Zn}, \mathrm{B}$, and $\mathrm{Fe}$, with $\mathrm{B}$ having the highest retranslocation rate $(60 \%)$. The only nutrients retranslated from deciduous leaves to senescent leaves were $\mathrm{Zn}, \mathrm{B}$, and $\mathrm{Mn}$. 


\section{Discussion}

Photosynthesis is variable between the leaves of the same plagiotropic branch. Young and senescent leaves have less photosynthesis, the first because they do not have all of the photosynthetic apparatus formed and the second because they are depleted due to the retranslocation of nutrients. The highest rates of photosynthesis occur in index leaves, which have a high concentration of nutrients and fully developed biochemical apparatus for photosynthesis. In sun leaves under saturation $1.000 \mu \mathrm{mol} \mathrm{m} \mathrm{m}^{-2} \mathrm{~s}^{-1}$, the values of $A$ and $\mathrm{g}_{s}$ are larger, with $55 \%$ greater values than in shaded leaves (Martins et al., 2014).

In addition to differences between leaves of the same branch, there are differences in photosynthesis between cultivars, which is due to genotypes within the same species adapting to the restrictions of the environment (Guo et al., 2002).

The young leaf showed higher stomatal conductance, which may be related to a higher $K$ content in that leaf. It is important that the plant is well nourished with $\mathrm{K}$, as it acts as an osmoregulator that contributes to the control of the stomatal opening and closing, changing the $\mathrm{CO}_{2}$ influx (Mao et al., 2018). In addition, high temperatures induce stomatal closure, providing less $\mathrm{CO}_{2}$ influx to the leaves and reducing photosynthesis (DaMatta et al., 2010).

The index sheet has a greater water-use efficiency, and the amount of water needed to fix $1 \mu \mathrm{mol}$ of $\mathrm{CO}_{2}$ is less on that sheet. This may be related to the $\mathrm{K}$ content in the index leaf, since it was relocated to the young leaf, resulting in less stomatal opening.

The distribution of chlorophyll $a, b$, and total chlorophyll in the leaves follows the same pattern as in photosynthesis; these pigments are related to the capture of light, so it is expected that a greater accumulation in the index leaf is expected. Leaves that develop in shaded environments have a higher concentration of chlorophyll per unit mass, resulting in a greater light uptake (Lambers et al., 2008). However, in this study, leaves that were shaded showed lower concentrations of chlorophyll $a, b$, and total chlorophyll, but increased carotenoids concentrations.

The levels of carotenoids in the leaves follow an inverse pattern of the other pigments, as it is related to photoprotection. It is expected to present low levels in leaves that are photosynthetically active. The reduction observed in the index leaf may be related to the dilution effect and not a reduction in that pigment. Carotenoids have a photoprotective action, dissipating excess light energy (McElroy and Kopsell, 2009).

Nitrogen, despite its high mobility in phloem, was not the most retranslated nutrient. $\mathrm{N}$ plays an important role in the expansion of the leaf area. In the formation of flower buds, it is found mainly in chloroplasts, being part of the chlorophyll molecule (Carvalho et al. 2010). Chlorophyll is the main nitrogen reserve. After the degradation of chlorophyll, $\mathrm{N}$ is retranslated via the phloem, where it is redirected to other developing organs (Maillard et al., 2015). The highest rate of retranslocation was $P$, which may be related to the characteristics of Cerrado soils. Soils rich in iron and aluminium have a high affinity with $P$. After the contact of phosphorus with the solid phase of the soil, its availability decreases, affecting the absorption of this nutrient by the vegetable. In young coffee plants, the low availability of $P$ reduces the total dry matter of the plant by up to 50\%, impairing coffee growth (Neto et al., 2016).
During the leaf collection period, the coffee plants were in full bloom, so part of the stored $\mathrm{P}$ would be relocated to the flowers and subsequent fruit development. The period of greatest $P$ accumulation in fruits occurs between 83 and 88 days after anthesis, which increases the demand for nutrients in this phase, especially in crops with high production potential (Laviola et al., 2009).

The $\mathrm{K}$ retranslocation of the index leaf to the young leaf in the Red Catuaí IAC 144 variety was 66.72\%, which was higher than that of $\mathrm{N}$. The $\mathrm{K}$ is used more intensively than $\mathrm{N}$ (Lima Filho \& Malavolta, 2003), mainly in flowering and grain formation, as it is involved in the synthesis and transport of carbohydrates to the fruits (Carvalho et al., 2010).

Ca does not show mobility in the phloem after its absorption and fixation in the cellular structures; there is no retranslocation, which causes it to present greater accumulations in older leaves (Marques et al., 2018). However, Ca availability is important for fruit development because it acts in the processes of cell division and the stabilisation of membranes and cell walls of new cells formed (Marenco and Lopes, 2005).

There was a $55 \% \mathrm{Mg}$ retranslocation from the index leaf to the young leaf in the Red Catuaí IAC 144 variety, and the IAC $125 \mathrm{RN}$ variety showed $41.94 \%$ retranslocation in the same leaf. The retranslocation of $\mathrm{Mg}$ from the older leaves to the younger leaves is usually intense and important in the formation of chlorophyll. In addition, fruits in the pellet phase demand high amounts of $\mathrm{Mg}$; therefore, it must have adequate levels of availability during this phase of fruit development (Carvalho et al., 2010; Laviola et al., 2009).

The retranslocation of $\mathrm{S}$ was similar to that of $\mathrm{Mg}$, both for the Red Catuaí IAC 144 and IAC 125 RN varieties. The period of greatest demand for $S$ in fruit growth is in the transition from green to ripe fruits (Valarini et al., 2005).

The retranslocation of micronutrients occurs with greater intensity from the index leaf to the young leaf, only Fe in the variety Red Catuaí IAC 144, which presented a $44.23 \%$ retranslocation of the senescent leaf to the index leaf. In a study carried out in Costa Rica to verify the accumulation of micronutrients in the Caturra variety, it was found that the highest percentages of $\mathrm{Fe}, \mathrm{Cu}$, and $\mathrm{Mn}$ accumulation occurred between 90 and 120 days after anthesis (Ramírez et al., 2002). In the varieties under study, $\mathrm{Zn}$ showed retranslocation from the index leaf to the young leaf. $\mathrm{Zn}$ has low mobility in plants; however, at high concentrations, there may be retranslocation (Silber et al., 2018). Coffee fruits have a higher demand for $\mathrm{Zn}$ during the same period of greatest vegetative growth of coffee, which extends from September to May (Partelli et al., 2013). This period of overlap may generate competition for nutrients between the vegetative and reproductive parts (Marré et al., 2015).

$B$ is a poorly mobile micronutrient in the phloem of many species and is not relocated to other organs (Carvalho et al., 2010). Most of the B is complexed or bound to the cell wall, preventing it from being relocated in the plant (Matoh et al., 1992). In this study, B retranslocation occurred in both cultivars. In situations where the plant is well nourished in B, part of this nutrient will be free and can be relocated via the phloem (Matoh, 1997). The varieties under study had levels of $B$ within the appropriate range, which is between $50-60$ $\mathrm{mg} \mathrm{kg}^{-1}$ for crops in production (Malavolta, 1993).

In addition to the questions related to soil characteristics, it is important to observe the mobility of the nutrients in the plant, to determine the moment of application of nutrients and the number of instalments. Nutrients that are not very 
Table 1. Nutrient content according to the types of leaves analysed and coffee varieties

\begin{tabular}{|c|c|c|c|c|c|c|c|c|}
\hline \multicolumn{5}{|c|}{ Red Catuaí IAC 144} & \multicolumn{2}{|l|}{ IAC $125 \mathrm{RN}$} & \multirow[b]{2}{*}{ Senescent Leaf } & \multirow[b]{2}{*}{ Deciduous Leaf } \\
\hline & Young Leaf & Index Sheet & Senescent Leaf & Deciduous Leaf & Young Leaf & Index Sheet & & \\
\hline \multicolumn{9}{|c|}{ - } \\
\hline $\mathrm{N}$ & $37.0 \mathrm{Ab}$ & $28.5 \mathrm{Ba}$ & $18.9 \mathrm{Ca}$ & $19.2 \mathrm{Ca}$ & $40.4 \mathrm{Aa}$ & $27.7 \mathrm{Ba}$ & $20.7 \mathrm{Ca}$ & $20.6 \mathrm{Ca}$ \\
\hline $\mathrm{P}$ & $3.9 \mathrm{Ab}$ & $1.9 \mathrm{Ba}$ & $0.9 \mathrm{Cb}$ & $0.8 \mathrm{Ca}$ & $4.5 \mathrm{Aa}$ & $2.0 \mathrm{Ba}$ & $1.2 \mathrm{Ca}$ & $1.0 \mathrm{Da}$ \\
\hline K & $27.7 \mathrm{Aa}$ & 18.3 Ba & 15.5 Ba & $15.7 \mathrm{Ba}$ & $22.7 \mathrm{Ab}$ & 17.1 Ba & 16.1 Ba & $14.3 \mathrm{Ba}$ \\
\hline $\mathrm{Ca}$ & 10.9 Da & $16.3 \mathrm{Ca}$ & $22.2 \mathrm{Ba}$ & $25.4 \mathrm{Aa}$ & $8.1 \mathrm{Db}$ & $13.4 \mathrm{Cb}$ & $21.6 \mathrm{Ba}$ & $25.5 \mathrm{Aa}$ \\
\hline $\mathrm{Mg}$ & $2.9 \mathrm{Aa}$ & $2.6 \mathrm{Ba}$ & $3.0 \mathrm{Aa}$ & 3.2 Aa & $2.2 \mathrm{Bb}$ & $2.1 \mathrm{Bb}$ & $2.4 \mathrm{Bb}$ & $2.8 \mathrm{Ab}$ \\
\hline$S$ & $2.1 \mathrm{Aa}$ & $2.1 \mathrm{Aa}$ & $2.2 \mathrm{Ab}$ & $2.0 \mathrm{Ab}$ & $1.9 \mathrm{Bb}$ & $2.0 \mathrm{Ba}$ & $2.4 \mathrm{Aa}$ & $2.4 \mathrm{Aa}$ \\
\hline \multicolumn{9}{|c|}{ - } \\
\hline$B$ & $48.6 \mathrm{Ab}$ & $48.3 \mathrm{Ab}$ & $49.6 \mathrm{Ab}$ & $48.3 \mathrm{Ab}$ & $75.1 \mathrm{Ba}$ & $97.3 \mathrm{Aa}$ & $62.5 \mathrm{Ca}$ & $51.8 \mathrm{Ca}$ \\
\hline $\mathrm{Fe}$ & $76 \mathrm{Ca}$ & $1136 \mathrm{Ca}$ & $2089 \mathrm{Bb}$ & $3897 \mathrm{Aa}$ & $702 \mathrm{Da}$ & $1045 \mathrm{Ca}$ & $2480 \mathrm{Ba}$ & $3487 \mathrm{Ab}$ \\
\hline $\mathrm{Cu}$ & $49 \mathrm{Ba}$ & $55 \mathrm{ABa}$ & $58 \mathrm{ABa}$ & $65 \mathrm{Aa}$ & $51 \mathrm{Ba}$ & $43 \mathrm{Bb}$ & $54 \mathrm{Ba}$ & $58 \mathrm{Aa}$ \\
\hline $\mathrm{Mn}$ & $58 \mathrm{Aa}$ & $37 \mathrm{Aa}$ & $95 \mathrm{Ab}$ & $108 \mathrm{Ab}$ & $73 \mathrm{Ba}$ & $112 \mathrm{Ba}$ & $268 \mathrm{Aa}$ & $302 \mathrm{Aa}$ \\
\hline $\mathrm{Zn}$ & $103 \mathrm{Aa}$ & $79 \mathrm{Ba}$ & $91 \mathrm{Ba}$ & $87 \mathrm{Bb}$ & $113 \mathrm{Aa}$ & $83 \mathrm{Ca}$ & $99 \mathrm{Ba}$ & $106 \mathrm{Aba}$ \\
\hline
\end{tabular}

Means followed by the same capital letter do not differ between the types of leaves and means followed by the same lower-case letter do not differ between varieties by the Student-NewmanKeuls (SNK) test at $5 \%$ significance. YL: young leaf; IS: index sheet; SL: senescent leaf; DL: deciduous leaf.

Table 2. Rate of macro- and micronutrient retranslocation in coffee leaves of the Red Catuaí IAC 144 and IAC 125 RN varieties.

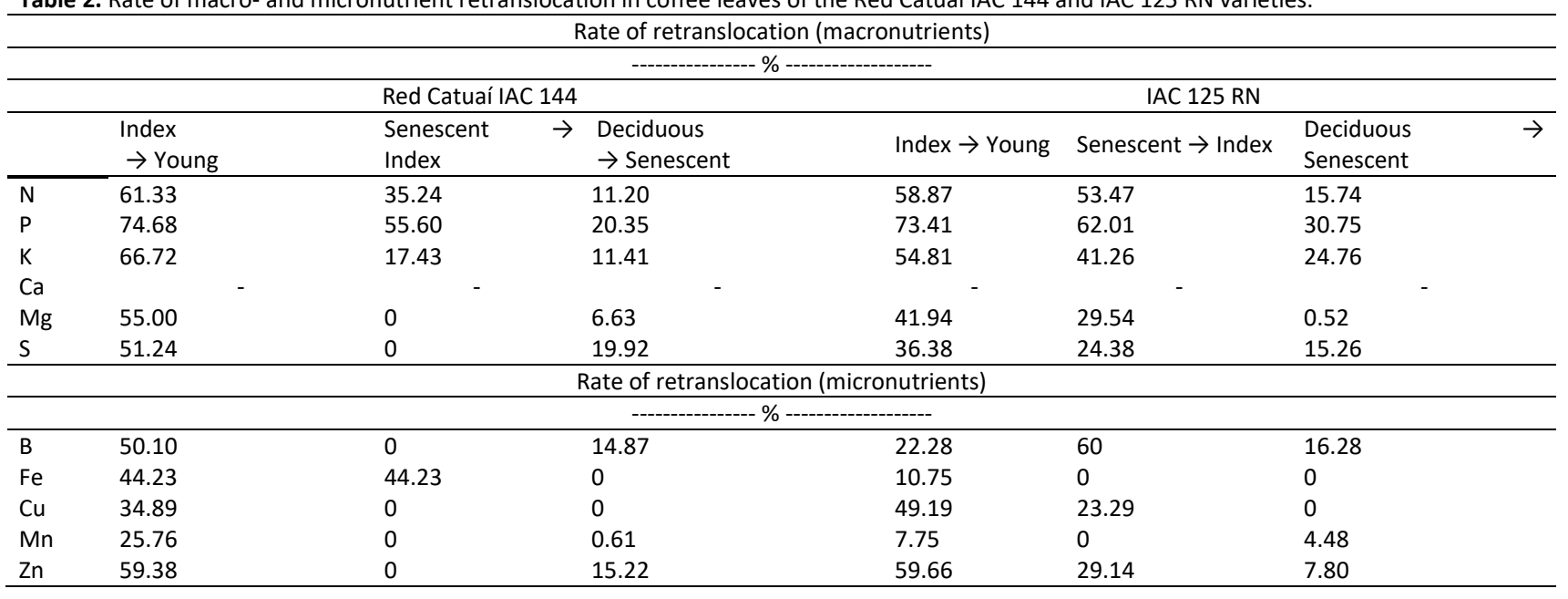
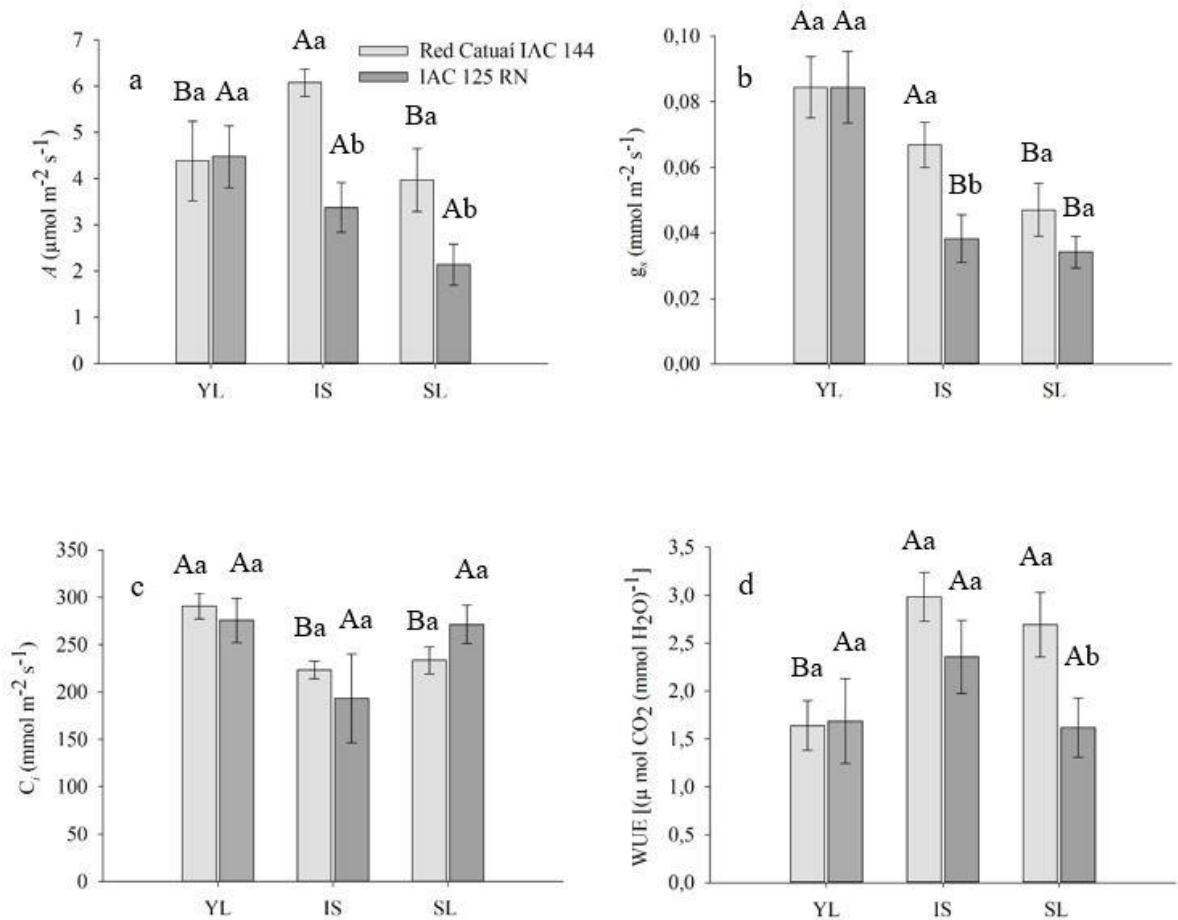

Fig 2. Photosynthesis $A(a)$, stomatal conductance $g_{s}(b)$, internal concentration $C_{i}(c)$, water-use efficiency WUE (d). YL, young leaf; IS, index sheet; $\mathrm{SL}$, senescent leaf. Means followed by the same capital letter do not differ between the sheets analysed by the Student-Newman-Keuls test (SNK) at $5 \%$ significance. Means followed by the same lower-case letter do not differ between cultivars by the SNK test (SNK) at $5 \%$ significance. 

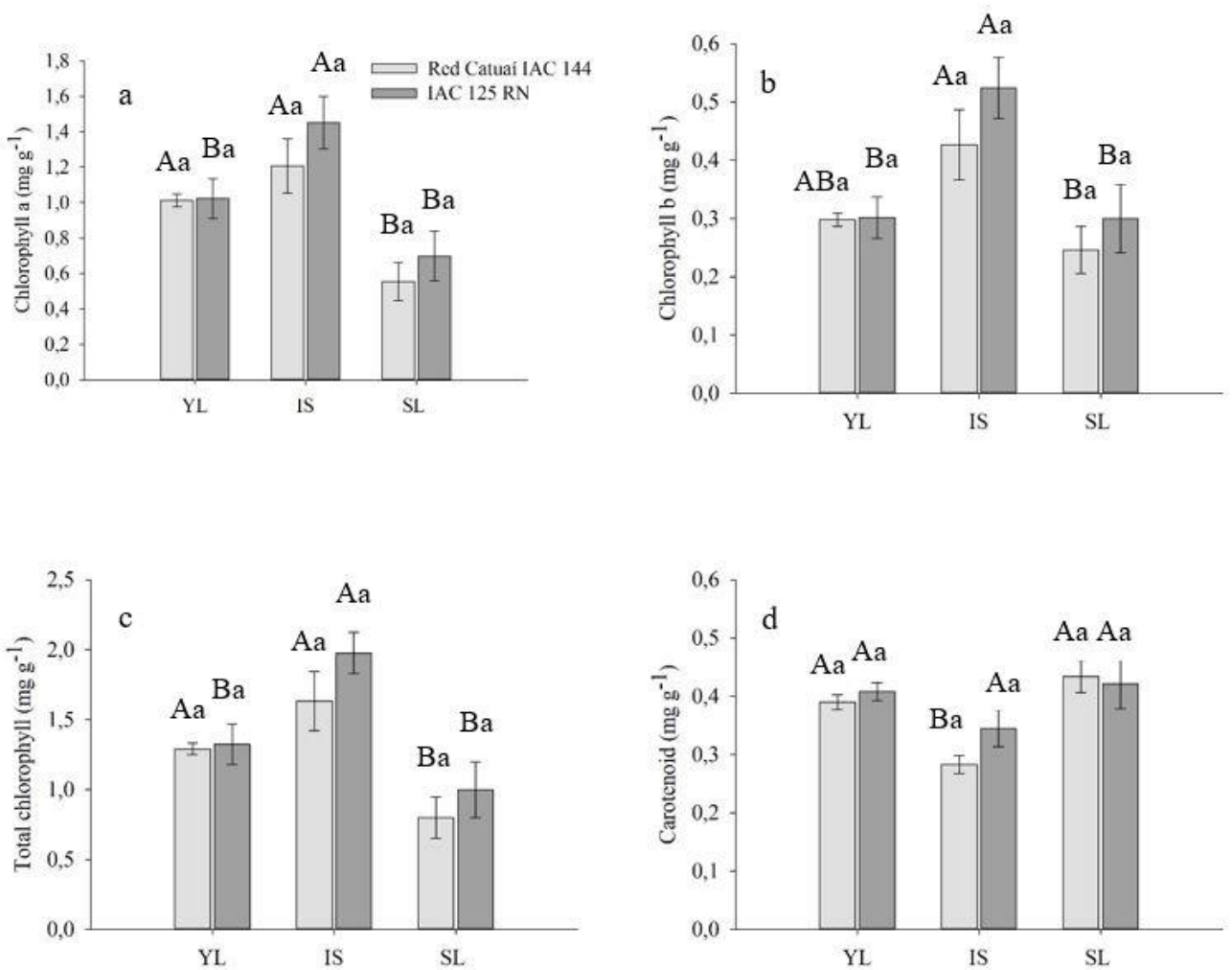

Fig 3. Chlorophyll $a(\mathrm{a})$, chlorophyll $b$ (b), total chlorophyll (c), and carotenoids concentrations (d). YL: young leaf; IS: index sheet; SL: senescent leaf. Means followed by the same capital letter do not differ between the sheets analysed by the Student-Newman-Keuls test (SNK) at $5 \%$ significance. Means followed by the same lower-case letter do not differ between cultivars by the SNK test at $5 \%$ significance.

mobile in the plant must be applied in instalments to meet the demand for organs that are under development. The nutrients that are mobile in the plant, such as $\mathrm{N}$ and $\mathrm{K}$, can be provided in a few applications; however, the mineralogy of the soil must be observed because they are liable to leach. For nutrients that have mobility in the plant, an alternative method is to supply them at the end of the agricultural cycle when the rainy season ends. This nutrient will be stored in the roots, stem, or leaves. Later, when the plant is in full bloom with a greater nutritional demand, these nutrients may be relocated to meet the initial development of the flowers and fruits. In this experiment, it was found that nutrition directly influences physiological and biochemical factors; therefore, an adequate supply of nutrients with application in instalments and in periods of greater demand enhances the physiological and biochemical parameters. It is also a better use of the nutrients; this method prevents them from accumulating in the system and becoming factors of environmental contamination.

\section{Materials and methods}

\section{Experimental area}

The experiment was installed in a commercial coffee

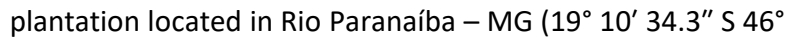
06' 23.8" W) in September 2018, with the Red Catuaí IAC 144 and IAC $125 \mathrm{RN}$ varieties. The crops were installed in December 2016 at a spacing of $3.70 \times 0.63 \mathrm{~m}$, with a drip irrigation system. The climate of the region is classified as Cwa, a humid temperate with dry winter and hot summer, and the rainy period is concentrated in the months from October to March (Alvares et al., 2013).

\section{Description of treatments}

The treatments consisted of two varieties of coffee (Red Catuaí IAC 144 and IAC 125 RN) and coffee leaves in four phenological stages. Young leaves were those located in the first pair of fully expanded leaves, diagnostic leaves were located in the third pair, senescent (chlorotic) leaves were located closer to the orthotropic branch and deciduous leaves, freshly fallen leaves were located in the canopy projection of the plants under study, in six repetitions with six plants per repetition. Four leaves were harvested from each phenological stage per plant, and the crop was in full bloom. The collections were performed in the middle third of the coffee plants, a portion of the plant commonly used to collect plant material (Matiello et al., 2015). For the analysis of nutrients, the treatments consisted of two varieties of coffee (Red Catuaí IAC 144 and IAC 125 RN) and coffee leaves in four phenological stages (young leaves, diagnostic, senescent and deciduous) a completely randomised design in a factorial scheme $(2 \times 4)$ was adopted. For gas and pigment analysis, the treatments consisted of two varieties of coffee (Red Catuaí IAC 144 and IAC $125 \mathrm{RN}$ ) and coffee leaves in three phenological stages (young leaves, diagnostic, and senescent). For gas exchange analysis, readings were made on leaves from the three phenological stages, and later these leaves were harvested for pigment analysis. For the analysis of gas and pigment exchanges, a completely randomised design in a factorial scheme $(2 \times 3)$ was adopted.

\section{Characteristics of cultivars}

The choice of these varieties for the installation of the experiment followed the agronomic criteria and the contrasting characteristics between them. 


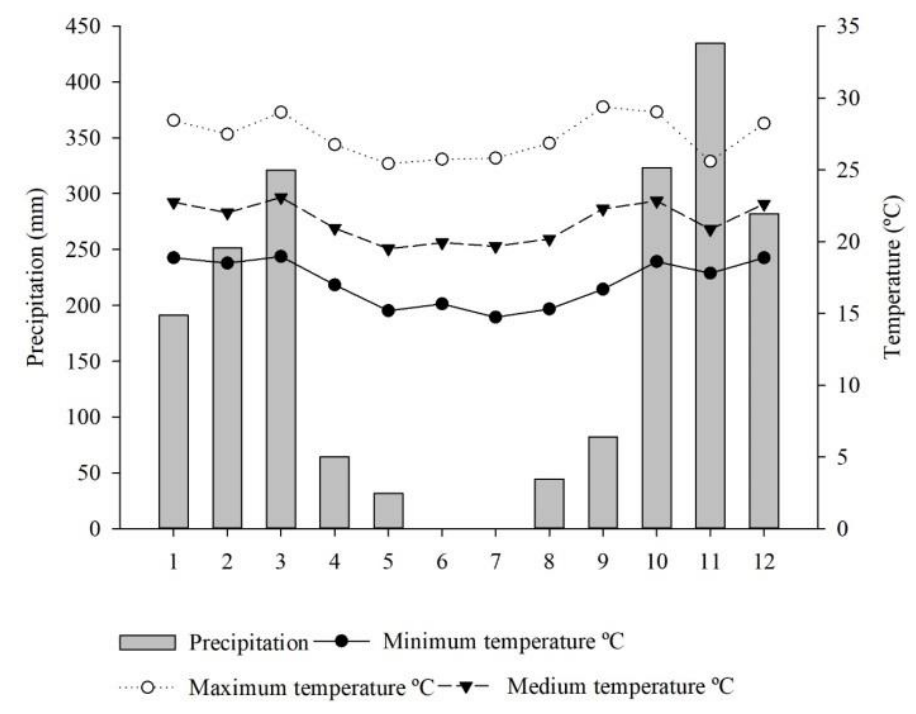

2018

Fig 1. Maximum, average, and minimum temperatures and monthly rainfall for the year 2018 in Rio Paranaíba, Minas Gerais.

The Red Catuaí IAC 144 variety is small, has short internodes, abundant secondary branching, and red fruits (Carvalho, 2008). The average productivity of Red Catuaí IAC 144 is approximately 35.28 bags ha ${ }^{-1}$, grains with medium sieve 16 (Lima et al., 2016). IAC $125 \mathrm{RN}$ is a small variety with superior drink quality, good productivity, medium sieve 17 , high resistance to rust and Meloidogyne exigua, demands more nutrition and is more sensitive to drought than is the Red Catuai variety IAC 144; it is recommended to prune crops in shorter periods (up to 10 years) (Matiello et al., 2015).

\section{Physiological analyses}

To verify the photosynthetic efficiency of the leaves in the different phenological stages, photosynthetic rate evaluations were made $\left(\mu \mathrm{mol} \mathrm{CO}_{2} \mathrm{~m}^{-2} \mathrm{~s}^{-1}\right)$, as well as the stomatal conductance $\mathrm{g}_{s}\left(\mathrm{~mol} \mathrm{H}_{2} \mathrm{O} \mathrm{m}^{-2} \mathrm{~s}^{-1}\right)$, internal concentration of $\mathrm{CO}_{2}\left(\mathrm{mmol} \mathrm{m}^{-2} \mathrm{~s}^{-1}\right)$, and instant efficiency in the use of water $\left[\left(\mu \mathrm{mol} \mathrm{m} \mathrm{m}^{-2} \mathrm{~s}^{-1}\right) /\left(\mathrm{mmol} \mathrm{H}_{2} \mathrm{O} \mathrm{m}^{-2} \mathrm{~s}^{-1}\right)\right]$. All described variables were analysed in the morning (08:00 10:00 h) under saturated artificial light $\left(1200 \mathrm{mmol} \mathrm{m}^{-2} \mathrm{~s}^{-1}\right)$ and an ambient concentration of $\mathrm{CO}_{2}$, using a portable infrared gas analyser.

\section{Chlorophyll analysis}

After leaf collection for pigment analysis, $0.1 \mathrm{~g}$ of plant tissue was removed from each leaf in the three phenological stages. Then, $0.1 \mathrm{~g}$ of tissue was placed in a falcon tube and $10 \mathrm{~mL}$ of $80 \%$ acetone was added and left for $72 \mathrm{~h}$ in the dark. After $72 \mathrm{~h}$, the material was poured into a cuvette and measured using a UV visible spectrophotometer at wavelengths of 645 and $663 \mathrm{~nm}$ for chlorophyll $a$, chlorophyll $b$, and total chlorophyll concentrations: and 475 $\mathrm{nm}$ for carotenoids concentrations.

\section{Determination of nutrients}

To determine the nutrients, the leaves were collected and washed immediately afterwards with distilled water to remove any impurities; later, they were dehydrated in an oven with forced air circulation at $70^{\circ} \mathrm{C}$ for $72 \mathrm{~h}$.
Subsequently, the dried leaves were ground in a Willey mill equipped with a $1 \mathrm{~mm}$ sieve. The samples were digested in nitro-perchloric solution and the nutrients $\mathrm{P}, \mathrm{K}, \mathrm{Ca}, \mathrm{Mg}, \mathrm{S}, \mathrm{B}$, $\mathrm{Fe}, \mathrm{Cu}, \mathrm{Mn}$, and $\mathrm{Zn}$ were quantified (Embrapa, 2009). To determine $\mathrm{N}$, the samples were subjected to sulphuric digestion (Miyazawa, 2009).

\section{Nutrient retranslocation}

The retranslocation of nutrients in the leaves was estimated according to the method described by Vitousek and Sanford (1986), which considers the retranslocation of $\mathrm{Ca}$, a practically immobile element, which served as a reference. For this study, the equation adapted by Chuyong, Newbery, and Songwe (2000) was used (Equation).

$\mathrm{NR}(\%)=\left\{1-\left[\left(\frac{\mathrm{NL}}{\mathrm{CaLO}}\right) /\left(\frac{\mathrm{NL}}{\mathrm{CaLY}}\right)\right]\right\} \times 100$

where:

$\mathrm{NR}(\%)=$ nutrient retranslocation rate;

$\mathrm{NL}=$ nutrient evaluated on the leaf;

$\mathrm{CaLO}=\mathrm{Ca}$ in the chronologically oldest leaf;

$\mathrm{CaLY}=\mathrm{Ca}$ in the chronologically youngest leaf.

\section{Statistical analysis}

Data on gas exchange, pigments, and nutrient content were subjected to analysis of variance, and the effects of treatments were compared using the Student-NewmanKeuls (SNK) test at $5 \%$.

\section{Conclusions}

The efficiency of water use by the leaf is related to the $\mathrm{K}$ content. Nutrients that have little mobility in the plant should be applied in instalments, meeting the demand for developing organs. $\mathrm{B}$ and $\mathrm{Zn}$ in high concentrations in the leaves can be relocated via the phloem. $\mathrm{Zn}$ was the most retranslated micronutrient; because of the difficulty of supply due to its high affinity with the mineral phase of the soil, foliar application may be an alternative. 


\section{Acknowledgment}

This study was financed in part by the Coordenação de Aperfeiçoamento de Pessoal de Nível Superior - Brasil (CAPES) - Finance Code 001. To CNPq and FAPEMIG for financial support for research.

\section{References}

Abdallah M, Dubousset L, Meuriot F, Etienne P, Avice JC, Ourry A (2010) Effect of mineral sulphur availability on nitrogen and sulphur uptake and remobilization during the vegetative growth of Brassica napus L. Journal of Experimental Botany. 61(10): 2635-2646.

Alvares CA, Stape JL, Sentelhas PC, Gonçalves JLM, Sparovek G (2013) Koppen's climate classification map for Brasil. Meteorologische Zeitschrift. 22(6): 711-728.

Avice JC, Etienne P (2014) Leaf senescence and nitrogen remobilization efficiency in oilseed rape (Brassica napus L.). Journal of Experimental Botany. 65(14): 3813-3824.

Bragança SM, Martinez HEP, Leite HG, Santos LP, Sediyama C, Alvarez VVH, Lani JA (2008) Accumulation of macronutrients for the conilon coffee tree. Journal of Plant Nutrition. 31(1): 103-120.

Brant AN, Chen HYH (2015) Patterns and mechanisms of nutrient resorption in plants. Critical Reviews in Plant Sciences. 34(5): 471-486.

Carvalho CHS (2008) Cultivares de café. (ed) Embrapa, Brasília. 247.

Carvalho JG, Guimarães RJ, Bastos ARR, Baliza DP, Gontijo RAN (2010) Sintomas de desordens nutricionais em cafeeiro. In: Guimarães RJ, Mendes ANG, Baliza DP (ed) Semiologia do cafeeiro: sintomas de desordens nutricionais, fitossanitárias e fisiologicas, Lavras. 215.

Clément G, Moison M, Soulay F, Reisdorf-Cren M, MasclauxDaubresse C (2018) Metabolomics of laminae and midvein during leaf senescence and source-sink metabolite management in Brassica napus L. leaves. Journal of Experimental Botany. 69(4): 891-903.

Chuyong GB, Newbery DM, Songwe NC (2000) Litter nutrients and retranslocation in a central African rain forest dominated by ectomycorrhizal trees. New Phytologist. 148(3): 493-510.

DaMatta FM, Grandis A, Arenque BC, Buckeridge MS (2010) Impacts of climate changes on crop physiology and food quality. Food Research International. 43(7): 1814-1823.

Diaz C, Lemaitre T, Christ A, Azzopardi M, Kato Y, Sato F, Morot-Gaudry J, Dily FL, Masclaux-Daubresse C (2008) Nitrogen Recycling and Remobilization Are Differentially Controlled by Leaf Senescence and Development Stage in Arabidopsis under Low Nitrogen Nutrition, Plant Physiology. 147: 1437-1449.

EMBRAPA - Embrapa Solos (2009) Manual de análises químicas de solos, plantas e fertilizantes. $2^{\text {rd }}$ edn. Brasília. 627.

Guo J, Jermyn WA, Turnbull MH (2002) Diurnal and seasonal photosynthesis in two asparagus cultivars with contrasting yield. Crop Science. 42(2): 399-405.

Laviola BG, Martinez HEP, Souza RB, Salomão LCC, Cruz CD (2009) Macronutrient Accumulation in Coffee Fruits at Brazilian Zona DaMata Conditions. Journal of Plant Nutrition. 32(6): 980-995.

Lambers H, Chapin IFS, Pons TL (2008) Plant Physiological Ecology. New York, - Publishing company Springer. 604.
Lima A E, Mendes ANG, Carvalho GR, Botelho CE, Castro EM, Cardoso DA (2016) Agronomic performance of 'Bourbon's' group coffee plants populations. Coffee Science. 11(1): 22-32.

Lima Filho OF, Malavolta E (2003) Studies on mineral nutrition of the coffee plant (Coffea arabica L. CV. Red catuaí). LXIV. Remobilization and re-utilization of nitrogen and potassium by normal and deficient plants. Brazilian Journal of Biology. 63(3): 481 - 490.

Malavolta E (1993) Nutrição mineral e adubação do cafeeiro. Agronômica Ceres, São Paulo. 126.

Malavolta E, Favarin JL, Malavolta M, Cabral CP, Heinrichs R, Silveira JSM (2002) Repartição de nutrientes nos ramos, folhas e flores do cafeeiro. Pesquisa Agropecuária Brasileira. 37(7): 1017-1022.

Mao X, Zheng Y, Xiao K, Wei Y, Zhu Y, Cai Q, Chen L, Xie H, Zhang J (2018) OsPRX2 contributes to stomatal closure and improves potassium deficiency tolerance in rice. Biochemical and Biophysical Research Communications. 495(1): 461- 467

Marques LF, Souto JS, Cavalcante LF, Mesquita EF, Nascimento JAM (2018) Composição mineral e redistribuição de nutrientes em gravioleira. Pesquisa Agropecuária Pernambucana. 23(1): 1-5.

Marenco RA, Lopes NF (2005) Fisiologia Vegetal: Fotossíntese, respiração, relações hídricas e nutrição mineral. Editora UFV, Viçosa. 451.

Marré WB, Partelli FL, Espindula MC, Dias JRM, Gontijo I, Vieira HD (2015) Micronutrient Accumulation in Conilon Coffee Berries with Different Maturation Cycles. Revista Brasileira de Ciência do Solo. 39(5): 1456-1462.

Martins SCV, Galmés J, Cavatte PC, Pereira LF, Ventrella MC, DaMatta FM (2014) Understanding the Low Photosynthetic Rates of Sun and Shade Coffee Leaves: Bridging the Gap on the Relative Roles of Hydraulic, Diffusive and Biochemical Constraints to Photosynthesis. PLOS One. 9(4): 1-10.

Matiello JB Santinato R, Almeida SR, Garcia AWR (2015) Cultura de café no Brasil: Manual de recomendações, Futurama. 585.

Matoh T, Ishigaki KI, Mizutami M, Matsunaga W, Takabe K (1992) Boron nutrition of cultured tobacco BY-2 cells: I. Requirements for an intracellular localization of boron and selection of cells that tolerate low levels of boron. Plant and Cell Physiology. 33(8): 135-141.

Matoh T (1997) Boron in plant cell wall. Plant and Soil. 193(2): 59-70.

McElroy JS, KopselL DA (2009) Physiological role of carotenoids and other antioxidants in plants and application to turfgrass stress management. New Zealand Journal of Crop and Horticultural Science. 37(4): 327-333.

Miyazawa M, Pavan MA, Muraoka T, Carmo CAFS, Melo WJ (2009) Análise química de tecido vegetal. In: Silva FC (ed) Manual de análises químicas de solos, plantas e fertilizantes $2^{\text {rd }}$ edn. Embrapa Informação tecnológica, Brasília. 191-233.

Neto AP, Favarin JL, Hammond JP, Tezotto T, Couto HTZ (2016) Analysis of phosphorus use efficiency traits in Coffea genotypes reveals Coffea arábica and Coffea canephora have contrasting phosphorus uptake and utilization efficiencies. Frontiers Plant Science. 7: 1-10.

Partelli FL, Marré WB, Falqueto AR, Vieira HD, Cavatti PC (2013) Seasonal vegetative growth in genotypes of Coffea canephora, as related to climatic factors. Journal of Agricultural Science. 5(8): 108-16. 
Ramírez F, Bertsch F, Mora L (2002) Consumo de nutrimentos por los frutos y bandolas de cafe Caturra durante un ciclo de desarrollo y maduracion en Aquiares, Turrialba, Costa Rica. Agronomía Costarricence. 26: 33-42.

Reichardt K, Silva AL, Fenilli TAB, Timm LC, Bruno IP, Volpe CA (2009) Relação entre a adubação nitrogenada e as condições hídricas do solo para um cafezal de Piracicaba, SP. Coffee Science. 4(1): 41-55.

Rena AB, Pereira AA, Bartholo GF (1983) Teor foliar de minerais, conteúdo caulinar de amido e o depauperamento de algumas progênies de cafés resistentes à ferrugem. In: Congresso Brasileiro de Pesquisa Cafeeira, 10., 1983, Poços de Caldas, Anais, Rio de Janeiro: IBC/GERCA.

Silber A, Naor A, Cohen H, Bar-Noy Y, Yechieli N, Levi M, Noy M, Peres M, Duari D, Narkis K, Assouline S (2018) Avocado fertilization: Matching the periodic demand for nutrients. Scientia Horticulturae. 241: 231-240.

Silva L, Marchiori PER, Maciel CP, Machado EC, Ribeiro RV (2010) Fotossíntese, relações hídricas e crescimento de cafeeiros jovens em relação à disponibilidade de fósforo. Pesquisa Agropecuária Brasileira. 45(9): 965-972.

Valarini V, Bataglia OC, Fazuoli LC (2005) Macronutrientes em folhas e frutos de cultivares de café arábica de porte baixo. Bragantia. 64(4): 661-672.

Vitousek PM, Sanford RL (1986) Nutrient cycling in moist Tropical forest. Annual Review of Ecology and Systematics. 17(2): 137-167.

White PJ (2012) Long-distance transport in the xylem and phloem. In: MARSCHNER, P. Marschner's mineral nutrition of higher plants. Academic Press, Croydon. 49-70. 